\title{
携帯端末のためのWebページからの概要文生成
}

\section{A Web Page Summarization for Mobile Phones}

\author{
長谷川 隆明 \\ 日本電信電話 (株) NTT サイバースペース研究所
NTT Cyberspace Labs., NTT Corporation \\ hasegawa.takaaki@lab.ntt.co.jp \\ 東京工業大学大学院総合理工学研究科知能システム科学専攻 \\ Tokyo Institute of Technology, Interdisciplinary Graduate School of Science and Engineering, Department of Computational Intelligence and Systems Science
}

\section{$\underset{\text { Hitoshi Nishikawa }}{\text { 西川 仁 }}$ \\ 今村 賢治}

菊井 玄一郎

奥村 学

\author{
日本電信電話 (株) NTT サイバースペース研究所 \\ NTT Cyberspace Labs., NTT Corporation \\ nishikawa.hitoshi@lab.ntt.co.jp \\ (同上) \\ imamura.kenji@lab.ntt.co.jp \\ (同上) \\ kikui.genichirodlab.ntt.co.jp \\ 東京工業大学精密工学研究所 \\ Tokyo Institute of Technology, Precision and Intelligence Laboratory \\ okulirpi.titech.ac.jp
}

keywords: summarization, sentence extraction, sentence compression, snippets, mobile phones

\section{Summary}

Recently, web pages for mobile devices are widely spread on the Internet and a lot of people can access web pages through search engines by mobile devices as well as personal computers. A summary of a retrieved web page is important because the people judge whether or not the page would be relevant to their information need according to the summary. In particular, the summary must be not only compact but also grammatical and meaningful when the users retrieve information using a mobile phone with a small screen. Most search engines seem to produce a snippet based on the keyword-in-context (KWIC) method. However, this simple method could not generate a refined summary suitable for mobile phones because of low grammaticality and content overlap with the page title. We propose a more suitable method to generate a snippet for mobile devices using sentence extraction and sentence compression methods. First, sentences are biased based on whether they include the query terms from the users or words that are relevant to the queries, as well as whether they do not overlap with the page title based on maximal marginal relevance (MMR). Second, the selected sentences are compressed based on their phrase coverage, which is measured by the scores of words, and their phrase connection probability measured based on the language model, according to the dependency structure converted from the sentence. The experimental results reveal the proposed method outperformed the KWIC method in terms of relevance judgment, grammaticality, non-redundancy and content coverage.

1.は じめ に

近年 , 携帯端末で閲覧することを前提とした Web ペー ジか増えたことに伴って，携帯端末向けWebページ専用 の検索サービスが実用化されている . また , 携帯端末向 けの Web ページだけでなくパソコン向けの Web ページ についても携帯電話から検索でき, 携帯端末向けに Web ページを変換して提示するサービスも存在している.検索 サービスに対する満足度を高めるには, 検索された Web ページを適切にランキングすることはもちろん重要であ るが, 検索されたページが適切かどうかを利用者に判断 させる情報を提示することも重要である．Web ページの 概要文 (スニペット) は, 利用者に提示される情報のひ
とつであり，概要文の良し悪しが検索エンジンの使い勝 手に大きな影響を与える．多くの検索エンジンでは，利 用者が入力した検索キーワードをできるだけ多く含むよ うに, KWIC (keyword-in-context)による方法を用いて Web ページから検索キーワードの周辺の文字列を切り出 したものを Web ページの概要文として提示していると推 測できる．パソコンで読むことを前提とした概要文では 概要文の長さに余裕があるため，KWIC による方法でも 検索キーワードの周辺から多くの文脈を得ることができ るので比較的実用に耐えると考えられる．しかしながら， 携帯端末で読むための概要文には, 携帯端末の画面が小 さいために提示できる文字数を少なくしなければならな いという制約がある．短い概要文の場合，KWICによる 
方法では主に $2 つ の$ 問題が生じると考えられる．ひとつ は，概要文の読みやすさが損なわれる問題である．概要 文が単語の途中の文字から始まったり単語の途中の文字 で終わったりする欠点は, 短い概要文では相対的に利用 者の目に付きやすくなるからである .もうひとつは，概 要文は Web ページのタイトルといっしょに利用者に提 示されるため, タイトルの内容と重複が生じる場合には, 概要文の持つ情報量が低下し利用者に有益な情報を提示 できないという問題がある．なぜならば，検索結果の上 位にランクされる Web ページにおいては，Web ページ のタイトルにも検索キーワードを含むことが多く, タイ トルと同等の内容を表す検索キーワード周辺の文脈を概 要文として提示することは十分に起こりえるからである このように，携帯端末て読むための概要文を利用者に提 示するためには，限られた少ない文字数でも読みやすく， Web ページの内容がわかるような概要文を生成すること が求められている.

本論文では, 上記の問題を解消するために, テキスト 要約の代表的な手法である重要文抽出と文短縮を用いる ことによって Web ページの概要文を生成する，我々は， すべての Web ページは文から構成されていると捉えて， まず利用者が入力する検索キーワードに適合する重要な 文を抽出し，次に弚の文を短縮するというアプローチを 取る．KWICによる方法に比べれは計算量は多くなるが， 検索時より事前にオフラインで処理できる計算が多いと 考えているため, 本論文では計算量の問題については論 じない .

本論文の構成は下記の通りである . はじめに，第 2 章 で関連研究について述べる，次に第 3 章で概要文を生成 するための新たな方法を提案する．第 4 章で実験につい て述へ，第 5 章で実験結果について考察する．最後に第 6 章で結論を述べる.

\section{2. 関 連 研 究}

本論文のスコープは，利用者からの検索要求に沿って Web ページを要約する技術である . 利用者の検索要求に 沿った要約は, ユーザに適応した動的な要約手法である これは,誰でもどんな目的にも沉用的に使える genericな 要約に対して , query-biasedな要約と呼ばれる. Tombros ら [Tombros 98] は, 重要文抽出における単語の重み付け の過程において検索質問に重みを加えることにより，検索 結果の出力における query-biased な要約の有効性を示し た .また，森 [森 02] は検索質問兴のものではなく，検索 質問により検索された文書をクラスタリングする際に得ら れる尺度である情報利得が大きい単語を用いて重要文を抽 出する手法を提案している.テキスト自動要約の評価に関 するワークショップ Document Understanding Conference (DUC)においても , generic な要約に加えて query-biased な要約が取り上げられてきた [Dang 06] .これらの方法
では, 新聞記事を対象としており，Web ページとはテキ ストの質が異なる . これらの方法をWeb ページに关のま ま適用した場合には次のような問題が生じると考えてい る . 1) 検索質問に含まれる単語に重みを加える重要文抽 出の手法をWeb ページに適用した場合，メニューを表す ような情報量の少ない文ゃ Web ページの主題とは無関 係な広告・宣伝を表す文を抽出してしまう可能性がある． 2)リード文を重要と考えてスコアを与えるという位置情 報を利用する手法では, タイトルと内容の重複した文が Web ページの先頭に存在する場合には，冗長な情報を利 用者に提示するという問題が発生する．3）また，クラス タリングを用いる方法を Web ページに適用しても，複数 の主題を含む Web ページから情報利得の高い話題語を適 切に抽出することは困難である .

新聞記事以外を対象とした先行研究では, Berger ら [Berger 00] は, 質問と光の回答からなる FAQ コーパス を利用した統計的な要約手法を提案したが, 学習のため のコーパスを必要とする . また, 高見ら [高見 08] は, 利 用者の検索目的に適した概要文を Web ページから動的に 再生成する方法を提案している．この方法では，概要文 を生成する際に考慮する Web ページの数という軸と内 容の包括要約性を考慮するかという軸を用いて概要文の 生成方法を4つのタイプに分類している. 乥して分類ご とに異なる尺度で重要語を獲得し, 弚れを利用した重要 文抽出により検索目的ごとに異なる概要文を生成してい る.我々は, 高見らの分類による 1 つの Web ページに対 して検索語を含むという基準で抽出された断片から生成 するタイプの概要文を対象とする.しかしながら，光の 分類で提案されている手法を改善するために，検索質問 に対する質問拡張的なアプローチを取ることや Web ペー ジのタイトルとの冗長性を排除することが必要であると 考えている. 光して, 以上の先行研究は, 携帯端末への 出力を目的とした要約方法ではないため, 要約の長さを 極端に短くすることは必要なく, 文書から検索質問に適 した文を選択する重要文抽出に基づいた方法に留まって いる*1.

一方，選択した文をさらに短くする文短縮の手法も提 案されている. 文短縮には構文情報を用いるアプローチ と構文情報は用いないアプローチがある.構文情報を用い るものとしては，機械学習を用いた方法 [Yamagata 06]， [Nomoto 08]や Noisy Channel に基づく方法 [Banko 00]， コーパスからの統計を用いた [酒井 02] が提案されてい る.しかしながら，提案されている文短縮の方法はいず れも generic な要約を指向したものであり, query-biased な要約を生成するためには, 検索要求ごとに別のコーパ

$* 1$ 実験に用いたデータにおける最重要文 199 文の長さを測定 した結果，特異値を外すために上位 10 文と下位の 10 文を除 外したところ, 平均値が 135 バイトで目標の要約長である 70 バイトを越える重要文は $69 \%$ を占めた．このことから，携帯端 末への出力を目的とした場合に, 重要文抽出だけでは不十分で あり，抽出した文をさらに短縮する必要がある． 
スが必要となるため，Web ページの概要文を生成するた めの文短縮に弚のまま適用できるかは不明である．また， 大森ら [大森 03] は, コーパスを用いずに携帯端末向けに 新聞記事を要約する方法を提案している．新聞記事は一 般に重要な情報から順に記述されているという特徵を利 用して，リード文に対する文短縮を行っている．リード 文の係り受け解析木の末端にある文節の中で, $\mathrm{tf} * \mathrm{idf}$ 值 が最も小さい文節から順に削除することで目標の要約の 長さまて短縮する．しかしながら，この手法は generic な 要約を生成することを目的としたものであり，本論文の 目的とは異なる.また，200 文字から 300 文字の新聞記 事に対して, 目標の要約の長さを 50 文字または 100 文 字としているため, 要約率としては 17\%から 50\%の設定 である . しかしながら , 多くの Web ページの検索サービ スでは, 検索結果の 1 画面に複数の Web ページの概要 文を並べることから，携帯端末に表示できる概要文の長 さはこの設定よりもさらに短い要約が求められる ${ }^{* 2}$. ま た，構文情報を用いないものとしては，単語を接合する 方法 [堀 01, 平尾 08]，あるいはルールに基づく方法 [山 本 05]か提案されている.これらの方法はロバストでは あるため，query-biased な要約に適用できる可能性があ るが, 対象となる文書の種類は音声認識結果や新聞記事 であり，文書のスタイル情報か講演や報道という均質な 状況であることを仮定している．このため，樣々なスタ イルが混在している Web ページに適用するには，Web

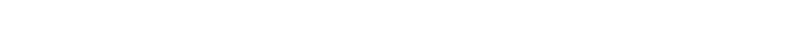
必要になるであろう．近年, Web ページの中でもテキス トの質が高くないとされるブログに対して，文節の係り 先が存在しない自己係りを導入することによる係り受け 解析器力提案されている [今村 07] . 係り受け解析の精度 が向上すれば，Webページの文短縮においても構文情報 を用いることは有用であると考えている．

以上のように，本論文では Web ページを対象とした query-biased な要約を指向し, 重要文抽出だけでなく文 短縮までもが必要な携帯端末向けの非常に短い概要文を 生成することを目的とする.このような目的の先行研究 はこれまでに存在しない .

\section{3. 携帯端末向けのテキスト 要約}

携帯端末向けにWeb ページを要約する方法について述 べる . はじめに要約のアプローチについて全体の流れを 述べ，兴の後に個々の技術について詳細を説明する .

\section{$3 \cdot 1$ アプローチ}

Web ページを要約するときの基本的な考え方は，検索 質問を考慮した重要文を抽出するために検索質問に対す

\footnotetext{
*2 実際に, 我々の用いたデータでは, 目標の要約の長さを 70 バイト (全角 35 文字) としたが, このときの要約率の平均は $2.56 \%$ であった . 新聞記事の要約率とは一桁違っていたことか ら，新聞記事よりもさらに難しいタスクであると言える
}

る各文の適合度を計算しておき，目的の要約長に達する まで最も適合度の高い文から順に抽出していくものとす る，ただし，画面の小さな携帯端末での表示に適応する ために, 目的の要約長が短い, つまり, 要約率が低いこ とを考慮して , 次のような改良を加える . (a) 検索結果は Web ページのタイトルとスニペットが同時に利用者に提 示されるので, 内容の重複を避けるために Web ページの タイトルと類似している文は抽出しないようにする . (b) 文を単位とする抽出では単位あたりの長さが長くなるた めに目的の要約長を有効に使えない場合もあるので，目 的の要約長を最大限利用するために必要に応じて文を短 縮する . 具体的には，選択しようとしている文を新規に あるいはすでに選択済みの文に追加することによって目 的の要約長を超える場合には，乥の文を追加しても目的 の要約長の範囲内に収まるように短縮する．つまり，目 的の要約長からすでに選択している文の長さを引いた長 さが，選択しようとしている文に許される最長の長さに なり，この長さの範囲で光の文を短縮する。例えば， 1 番 目に重要な文の長さが目的の要約長を越えるならば，光 の文は目的の要約長の範囲で短縮する .1 番目に重要な 文の長さが目的の要約長よりも短い場合は， 1 番目に重 要な文を弚のまま追加した後に 2 番目に重要な文を追加 しようとするが， 2 番目の文を追加することで目的の要 約長を越える場合は，目的の要約長から 1 番目の文の長 さを引いた長さの範囲において 2 番目の文を短縮する 抽出した文および短縮した文は出現順序に従って並び替 え，これらの間で原文から落ちた部分を記号「...」で置 換する . 抽出した文および短縮した文の長さの合計が目 的の要約長のある一定の割合を満たせば，重要文抽出と 文短縮を終了する．このように重要文抽出と文短縮を動 的に組み合わせるアプローチを取る .

以下に要約の流れを示す .

(1) Web ページからの HTML タグの除去・本文抽出

(2) 本文に対する文分割

(3) 検索質問に対する本文中の単語の重要度の計算

（4）Web ゚゚ージのタイトルとの冗長性排除による重要 文抽出

（5）検索質問を考慮した文短縮

Web ページの HTML タグの除去は, 単純に HTML タグ を削除するのみである．Web ページから HTML タグを 除去したテキストを本文とする*3(1)．本文に対する文分 割は句点と飾り記号および改行で区切られている箇所を 特定し文を切り出す (2). 検索質問に対する単語重要度の 計算 (3) と冗長性排除による重要文抽出 (4)，検索質問を 考慮した文短縮 (5)については以下でとれれ゙゙れ詳述する .

\footnotetext{
*3 Web ページから HTML タグを除去するだけなので, 広告等 を含む Web ページでは広告等が兴のまま残るが，広告等を含 めて本文として扱う.
} 


\section{$3 \cdot 2$ 検索質問を考慮した単語重要度の計算}

検索質問を考慮した重要文を抽出するために，検索質 問を考慮した単語重要度を計算する．検索質問を構成す る単語はもちろん重要であるが, 検索質問はたかだか数 単語なので炎れ以外にも検索質問と関連性の高い単語も 重要であると考えている．我々は検索質問と関連性の高 い単語とは検索質問と共起しやすい単語であると考え， 検索質問と Web ページに含まれる任意の単語との共起の しやすさを単語重要度に取り入れることを提案する．本 論文では, [Dunning 93] で提案された単語のバイグラム についての仮説検定の手法を流用し，検索質問 $q$ と文書 内の単語 $t$ 共起のしやすさ (相関の高さ) を計算する . まず, 何らかのコーパスを用いて，コーパスの全文書集 合において単語 $t$ を含む文書の出現確率 $p$ と，検索質問 $q$ を含む文書集合における単語 $t$ を含む文書の出現確率 $p 1$ ，および，検索質問 $q$ を含まない文書集合における単 語 $t$ を含む文書の出現確率 $p 2$ を計算する . もし検索質問 $q$ と単語 $t$ か独立 (無相関) であれば, 出現確率 $p 1$ と $p 2$ は等しくなり， $p$ とも等しくなるはずである．逆に検索質 問 $q$ と単語 $t$ が独立でない場合は, 出現確率 $p$ と $p 1, p 2$ は等しくならないはずである．この仮定を利用し，検索 質問 $q$ と単語 $t$ の相関を調べるために，検索質問 $q$ と単 語 $t$ か独立に出現するとした仮説と，検索質問 $q$ と単語 $t$ か独立でなく出現するとした仮説との尤度比を計算する それ炎れの仮説の尤度は 2 項分布を用いて計算する. 計 算式を式 (1) に示す. 式 (1)の分子は検索質問 $q$ と単語 $t$ が独立とする仮説の尤度, 分母は検索質問 $q$ と単語 $t$ が 独立でないとする仮説の尤度である . 検索質問 $q$ と単語 $t$ の共起のしやすさ (相関の高さ) として , これらの仮 説の尤度比 $(\lambda)$ による対数尤度比 $(-2 \log \lambda)$ を採用する 検索質問 $q$ と単語 $t$ が独立でない，つまり相関が高い場 合に, 尤度比 $(\lambda)$ は小さくなり, 対数尤度比 $(-2 \log \lambda)$ が 大きくなる .

$$
\lambda=\frac{L\left(c_{12}, c_{1}, p\right) L\left(c_{2}-c_{12}, N-c_{1}, p\right)}{L\left(c_{12}, c_{1}, p_{1}\right) L\left(c_{2}-c_{12}, N-c_{1}, p_{2}\right)}
$$

ただし

$$
\begin{aligned}
& p=\frac{c_{2}}{N} \\
& p_{1}=\frac{c_{12}}{c_{1}} \\
& p_{2}=\frac{c_{2}-c_{12}}{N-c_{1}} \\
& L(k, n, x)=x^{k}(1-x)^{n-k}
\end{aligned}
$$

とする .ここで $N$ は全文書数である . $c_{1}$ は検索質問の 文書頻度， $c_{2}$ は単語の文書頻度， $c_{12}$ は検索質問と単語 の共起頻度を表す . 検索質問と同じまたは検索質問に含 まれる単語についても，他の単語と同樣に検索質問と共 起するとみなして対数尤度比を計算する．ただし，計算 の都合上共起頻度から 1 を減じておく．
単語重要度は, 対数尤度比 (LLR) と文書頻度の逆数 (idf) の積とする . 検索質問 $q$ における単語 $t$ 単語重要 度を式 (6) に定義する。

$$
i m p(t)=-2 \log \lambda(q, t) * \log \frac{N}{d f(t)}
$$

ここで , $-2 \log \lambda(q, t)$ は検索質問 $q$ と単語 $t$ の対数尤度 比であり, $d f(t)$ は単語 $t$ を含む文書頻度である 。

\section{$3 \cdot 3$ 几長性を排除した重要文抽出}

検索質問を考慮した単語重要度に基づいて文を抽出す るが , Web ページのタイトルやすでに選択した文との内 容の重複を避けるために , Maximal Marginal Relevance (MMR)[Carbonell 98] を用いる.MMR の式 (7) に従って 重要文を抽出する .

$$
\begin{aligned}
\operatorname{MMR}(Q, R, S)= & \underset{P_{i} \in R \backslash S}{\operatorname{argmax}}\left\{\alpha \operatorname{Sim}_{1}\left(P_{i}, Q\right)\right. \\
& \left.-(1-\alpha) \max _{p_{j} \in S} \operatorname{Sim}_{2}\left(P_{i}, P_{j}\right)\right\}
\end{aligned}
$$

ただし， $Q$ は検索質問， $R$ は本文のすべての文， $S$ はす でに重要文として選択されている文， $R \backslash S$ はまだ重要文 として選択されていない文とする . $\operatorname{Sim}_{1}\left(P_{i}, Q\right)$ は検索 質問 $Q$ と文 $P_{i}$ との適合度を算出する関数で, Web ペー ジ内のメニューなどの短い文を避けて内容を多く含む長 い文を抽出するために, 文を構成する単語の単語重要度 の総和を用い，総和の最大值で正規化した值を採用する． $\operatorname{Sim}_{2}\left(P_{i}, P_{j}\right)$ は $S$ に含まれる文 $P_{j}$ と抽出候補の文 $P_{i}$ の間の内容の重複を避けるために計算する類似度で , コ サイン類似度を用いる。

検索エンジンは Web ページのタイトルの情報も利用 して Web ページのランキングを行っていることか想定さ れ, Web ページのタイトルに検索質問を含む Web ページ が上位にランキングされることが予想される．このため， Web ページのタイトルを 0 番目の文として考え , はじめ から $\mathrm{S}$ に入っている，つまりはじめからすでに選択され た文として扱うことで, Web ページのタイトルとの冗長 性を排除しながら，検索質問に適合する文を抽出する．

\section{4 文 短 縮}

文を抽出していく際に目的の要約長の範囲に収まらな い場合に文を短縮する . 抽出対象の文を係り受け解析し て得られる木構造に基づき, 目的の要約長の範囲で述部 をルートとする最適な部分木を選択する . 最適な部分木 を選択するために , 以下の $2 つ の$ 数值を組み合わせたス コアを提案する .

・検索質問を考慮した単語重要度に基づく文節網羅率

・文節同士のつながりやすさである文節連接確率

一方で, 文節網羅率を考慮することにより, 文の内容を 網羅するよう重要な単語を含む文節を多く含む部分木の スコアが高くなり, 他方で, 文節連接確率を考慮するこ とにより, 文としての読みやすさを向上するよう各文節 
同士のつながりやすさが大きい部分木のスコアが高くな る.計算されたスコアが最も大きい部分木を短縮文とす る.なお，文節連接確率では文節が文頭や文末になる確 率も計算する.

文節網羅率は式 (8) に定義する。

$$
P_{i m p}\left(w_{i}\right)=\frac{\sum_{t_{k} \in w_{i}} i m p\left(t_{k}\right)}{\sum_{w_{j} \in X} \sum_{t_{l} \in w_{j}} i m p\left(t_{l}\right)}
$$

ただし， $X$ は文全体， $w_{i}$ と $w_{j}$ は文節を表し， $t_{k}$ は文 節 $w_{i}$ に含まれる単語を, $t_{l}$ は文節 $w_{j}$ に含まれる単語を 表す。

文節連接確率は式 (9) に定義する。

$$
P_{a d j}\left(w_{i} \mid w_{i-1}\right)=P\left(f_{i} \mid f_{i-1}\right)
$$

ただし， $f_{i}$ は文節の内容語の主辞を表し， $f_{i-1}$ は文節の 機能語の主辞を表す . 文節の内容語の主辞とは, 文節に 存在する内容語列のうち最後尾のものを指す .これは, 日 本語では文節の代表単語はより後方に存在するためであ る.文節の機能語の主辞とは，文節に存在する機能語列 のうち句読点等の記号類を除く最後尾のものを指す . こ れは, 日本語では文節がどの文節と係り受け関係になる かを表す重要な指標となるためである．ただし，副詞文 節のように機能語がないものは内容語の主辞と同じ単語 になる.式(9)は文短縮した結果の短縮文において, 各文 節同士が隣り合う尤もらしさを表し， $P\left(f_{i} \mid f_{i-1}\right)$ はコー パスから最尤推定により求める.ある文節の機能語の主 辞は光の文節の最後尾となるので, 次に並心汶節の内容 語の主辞との連接確率を計算する .これは, 係り受け解 析で得られる部分木のうち, どの深さまでのノード (文 節) を選択するかを決定するのに寄与する．また，係り 受け解析に誤りがある場合でも，文節の連接を考慮する ことで, 光の誤りを回避することも期待される*4.

文節網羅率と文節連接確率に基づいて各部分木のスコ アを式 (10) に定義し，このスコアが最大となる述部を ルートとした部分木を要約対象である文の短縮文とする．

$$
\begin{aligned}
W^{*}= & \underset{W \in G(X)}{\operatorname{argmax}}\left\{\log \sum_{i=0}^{\operatorname{node}(W)-1} P_{\text {imp }}\left(w_{i}\right)\right. \\
& \left.+\frac{\sum_{i=0}^{\text {node }(W)} \log P_{\text {adj }}\left(w_{i} \mid w_{i-1}\right)}{\operatorname{node}(W)}\right\}
\end{aligned}
$$

ここで, $X$ は要約対象の文を， $G(X)$ は文 $X$ における 部分木の集合を, $W$ は部分木を, $\operatorname{node}(W)$ は部分木 $W$

\footnotetext{
$* 4$ 例えば,「いただいた/お薬は、/弱い/種類であるものの/ステロ イド系なので、珄まれて/間もない/赤ちゃんに/使うにとを/迷つ ています。」という文（文節の境を”尼する）を例に取ると， 仮に「生まれて」が「使う」に係ると誤って解析された場合に は、「使う」には他に「間もない赤ちゃんに」が係るとすると， 「間もない」だけか落ちて，「生まれて/赤ちゃんに/使う」とい う望ましくない部分木を含む非文が生成される可能性がある 係り受け解析に部分的に誤りがあったとしても，文節連接確率 を用いることにより，「生まれて」と「赤ちゃん」の連接確率が 小さいのであれば，このような非文が生成される確率も小さく なる .
}

を構成する文節数を表す．第 2 項の文節連接確率は文節 の少ない部分木のスコアが大きくなるため, 部分木の文 節数で幾何平均を取る. 文節網羅率と文節連接確率の重 みは，両者が同等であることに価値があると考え $1: 1$ と した。

\section{4. 実験}

\section{1 実 験 の 設 定}

提案した Web ページの概要文を生成する手法について 評価を行うために，実験を行った . 検索質問は NTCIR-4 Web Info1 情報指向検索タスク ${ }^{* 5}$ のサーベイ型クエリ 35 個のうち 20 個を用いた . Webページは検索エンジン，モ バイル goo*6を用いて各検索質問で検索され重複を除い た上位 10 件 (検索質問のひとつのみ 9 件) の携帯端末 向けページを収集した . 各 Web ページから HTML タグ を除去した後の全 199 ページのテキストの平均の長さは 2736 バイト，標本分散は 5823899 であった . 概要文の 生成の条件として目的の要約長を 70 バイトとした . 要 約率に換算すると平均 $2.56 \%$ となり極めて低い要約率と なる。

比較対象として KWIC (keyword-in-context) に基づく ベースラインを採用した ${ }^{* 7}$. KWIC は, 基本的には検索 質問で与えられるキーワードと炎の前後の文字列を抜粋 するが, 複数のキーワードがマッチする場合については キーワードの選び方が多樣になるため, 次のような手順 とした . まず，本文中に出現するすべてのキーワードの 位置を取得し，光れに基づき各キーワード，および，あ るキーワードから別のキーワードまでの文字列の範囲を 弚れ光れパートとする．パートは，目的の要約長を超え ない範囲で，3つ以上のキーワードを含んでもよい．次 に，目的の要約長を超えない 1 つ以上のパートの組み合 わせを候補とし，候補が 1 つになるまで以下の優先規則 を順次適用する．1)キーワードの異なり数が最も多い． 2)パート数が最も少ない.ただし , パート数は 2 までと し，パート同士をつなぐ箇所には記号「...」を挿入する． 3)キーワードの総数が最も多い，最後に, 目的の要約長 に達するように，決定した候補の各パートの前後から同 じ長さの文字列を付加する .

提案手法では, 単語重要度の計算に対数尤度比を用い るものと用いないもの，MMR を用いるものと用いない もの，文短縮を用いるものと用いないもので組み合わせ を作り，表 1 に示す 4 つハバリエーションを評価した . 単

\footnotetext{
*5 http://research.nii.ac.jp/ntcir/permission/ntcir-4/perm-jaWEB.html

*6 http://mobile.goo.ne.jp

*7 商用の検索エンジンの概要文生成は基本的には KWIC によ る方法と考えられるが，弚の具体的な方式は公開されていな い.このため, 商用の検索エンジンの概要文との比較により提 案手法の効果を測定することは難しい. 弚こで，KWIC に基づ くベースラインを実装することにより提案手法との比較を行っ た。
} 
表 1 提案手法のバリエーション

\begin{tabular}{l|l|l|l}
\hline \hline & 単語重要度 & MMR & 文短縮 \\
\hline 提案手法 (1) & $\mathrm{tf} * \mathrm{idf}$ 值 & 行う & 行わない \\
提案手法 (2) & $\mathrm{tf} *$ idf 值 & 行わない & 行う \\
提案手法 (3) & $\mathrm{tf} * \operatorname{idf}$ 值 & 行う & 行う \\
提案手法 (4) & LLR*idf 值 & 行う & 行う \\
\hline
\end{tabular}

語重要度が LLR*idf 値の場合は，式(6) を用いる．対数 尤度比の計算は形態素解析による品詞が名詞または未知 語である単語に限定し, 弚れ以外の単語の単語重要度は idf 值とした . idf 值の計算には, 品詞が名詞または未知 語である単語の文書頻度を用い, 弚れ以外の単語には一 定の小さな値を与えた . 単語重要度が tf*idf 值の場合は, 対数尤度比の変わりに文書内単語頻度 $t f(t)$ を用い, 式 (6)において $-2 \log \lambda(q, t)$ の変わりに $\log t f(t)$ て計算し た 、ただし，検索質問 $q$ に含まれる単語については計算結 果を二乗することで検索質問にバイアスをかけた . MMR を行う場合は式 (7)の $\alpha$ の值を 0.5 に設定し，MMRを 行わない場合は $\alpha$ の值を 1 に設定して第 2 項を無視し た . 文短縮を行う場合は，目的の要約長を超えて文を選 択する際に式(10)に従って目的の要約長を超えないよう に文を短縮し，目的の要約長の 8 割を満たせば重要文抽 出と文短縮を終了させた . 文短縮を行わない場合は, 要 約長を超えて文を選択する際に文短縮の代わりに，抽出 する文の文頭から目的の要約長までの残りのバイト数分 だけカットした . 提案手法で利用したデータを表 2 に示 す. 単語重要度を計算するための各単語についての文書 頻度および検索質問との共起頻度は表 2 のすべてを用い た。また，文短縮に用いる文節連接確率を求めるための 文節連接モデルを学習する際には，毎日新聞と Yahoo!知 恵袋データに対して係り受け解析器 [今村 07] を実行し，

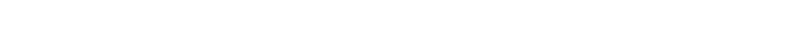
の連鎖からモデルを学習した ·ただし，機能語について は表記も利用した 。

評価方法は，被験者 3 名による主観評価とした。評価 基準については，Web ページの概要文として有効かとい う検索タスクの評価と, テキスト要約としての観点から 要約の評価を行った . 検索タスクの評価では，NTCIR-4 Web Info1 情報指向検索タスクの $<\mathrm{NARR}>$ タグに記載 されている判定基準に基づき，部分適合を含む適合と不 適合の 2 值による適合性判定を行った . 要約の評価では， 文法性の評価, タイトルを含めた非冗長性の評価, 内容 網羅性の評価を各 5 段階で行った $(5$ が最も良く 1 が最 も悪い). 文法性の評価では, 単語の途中で文が途切れて いないか，日付や記号を含まないかを評価した . 非冗長 性の評価では，Web ページのタイトルを含めて不必要な 情報の繰り返しがないかを評価した . 内容網羅性の評価 では, 概要文として不必要な情報を含んでいないか, 検 索質問に対して無関係の情報を含んでいないかを評価し
表 2 実験に用いたデータ

\begin{tabular}{l|r}
\hline \hline データ & 文書数 \\
\hline 毎日新聞 2003 年-2007 年 & 496,606 \\
Wikipedia & 511,120 \\
Yahoo!知恵袋 & $16,593,794$ \\
ブログ & $13,556,798$ \\
\hline
\end{tabular}

た ${ }^{* 8}$.

\section{$4 \cdot 2$ 実 験 結 果}

適合性判定の評価結果を表 3 に示す . 適合性判定の評 価は概要文 (要約)，Web ページ (原文) の順序で行っ た . 原文の適合性判定が適合となる文書を正解として用 い, 再現率, 適合率，F值で評価を行った。再現率と適 合率は以下のように定義する .

$$
\begin{aligned}
& \text { 再現率 }=\frac{\text { 概要文が適合かつ原文が適合の文書数 }}{\text { 原文が適合の文書数 }} \\
& \text { 適合率 }=\frac{\text { 概要文が適合かつ原文が適合の文書数 }}{\text { 概要文が適合の文書数 }}
\end{aligned}
$$

評価対象の 199 文書を評価者 3 名により評価したところ， 延べ文書数 $597(199 * 3=597)$ のうち 146 文書が適合 と判定された. 2 名 1 組とした 3 組の kappa 值の平均値 は 0.58 (moderate) であった. 表 3 から, Web ページの本 文を文として扱ったときに，(1) を除く提案手法はべー スラインの F 値を上回ることか確認できた . 最も F 值が 高かったのは提案手法の (4) であった . tf*idf 值と MMR による重要文抽出と文頭からのカット (1) では, 再現率 が低いためにベースラインの F 值を上回ることはできず， MMR を実行しないが文短縮を実行すること (2)ではじ めてベースラインの F 值を上回ることがわかった . 提案 手法の (1) と (3) は文短縮を実行するか否かの違いがあ り，これらを比べると再現率，適合率ともに向上したの で, 文短縮の有効性が明らかになった . また, 提案手法 の(2)と (3)は MMRを実行するか否かの違いがあり，こ れらを比べると文短縮ほどではないものの再現率，適合 率ともに向上し，MMR の有効性が確認できた . 提案手 法の (3) と (4) では対数尤度比を用いたか否かの違いが あり，適合率は下がるものの弚れ以上に再現率が上がり $\mathrm{F}$ 值が向上したことから, 対数尤度比の効果を確認でき る結果となった .

要約としての評価を表 4 に示す.ベースラインの KWIC と提案手法の各バリェーションに対して, 文法性, 非冗長 性, 内容網羅性を 5 段階で評価した . 文法性については,

\footnotetext{
$* 8$ 内容網羅性の評価については,「概要文として必要な情報と は何か」，また,「検索質問に対して関係のある情報とは何か」 を規定することか難しかったため,概要文として不必要な情報 を含んでいないか」と「検索質問に対して無関係の情報を含ん でいないか」という2つの基準を考慮して 5 段階の主観評価で

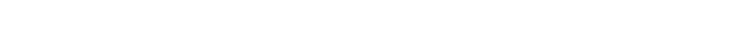
価が，どちらも満たさなければ悪い評価が与えられる．
} 
表 3 適合性判定の評価

\begin{tabular}{l|c|c|c}
\hline \hline & 再現率 & 適合率 & F 值 \\
\hline KWIC (ベースライン) & 0.760 & 0.457 & 0.571 \\
提案手法 (1) & 0.582 & 0.531 & 0.556 \\
提案手法 (2) & 0.623 & 0.532 & 0.574 \\
提案手法 (3) & 0.644 & 0.537 & 0.586 \\
提案手法 (4) & 0.719 & 0.522 & 0.605 \\
\hline
\end{tabular}

表 4 要約としての評価

\begin{tabular}{c|c|c|c}
\hline \hline & 文法性 & 非冗長性 & 内容網羅性 \\
\hline ベースライン & 2.85 & 4.27 & 1.75 \\
提案手法 (1) & $3.73(3.62)$ & 4.68 & 2.16 \\
提案手法 (2) & $4.09(4.02)$ & 4.61 & 2.14 \\
提案手法 (3) & $4.00(3.96)$ & 4.82 & 2.23 \\
提案手法 (4) & $4.11(4.08)$ & 4.81 & 2.32 \\
\hline
\end{tabular}

KWIC が最も評価が低く，次に文短縮を行わない提案手 法の (1)の評価が低かった . 文法性の評価では評価基準に 単語の途中て切れているかどうかを採用した .このため， KWIC では文境界を考慮せずに検索質問を含む周辺の文 字列を抜き出すので，評価を下げたと考えられる．文短 縮を行わない提案手法の (1) も文頭から指定の文字数を 抜き出すために，単語の途中で切れてしまう場合が発生 するので, 評価を下げたと考えられる. 実験では文抽出 のみの文法性評価を行わなかったが，これは KWICでも 文を単位とする拔粋ではないことと，文抽出のみに限定 すれば文法性は向上するかもしれないが目的の要約長を 大きく割り込むことで内容網羅性が著しく低下する可能 性を避けることによる．表４における文法性の括弧内の 数值は文を短縮あるいは先頭から抜粋したもののみを対 象とした評価結果であるが，光れでも提案手法はいずれ もベースラインを上回っている. 非冗長性では, 提案手 法の (2) と (3) を比べると，(2)よりも (3) の方が非冗長性 のスコアが大きいことから，MMR は非冗長性に有効で あるという結果が得られた .ただし，非冗長性について は文法性ほど差が出なかった .これは，実験に用いたす べての検索質問が複数のキーワードから構成されていた ので, Web ページのタイトルに複数のキーワードを含む 場合自体が少なく，概要文との冗長性が大きくはなかっ たためと考えられる．内容網羅性については，不適合文 書は検索質問に適合する情報を含むことは少ないと考え， 適合と判定された 146 文書のみで評価した . 70 バイトと いう非常に限られた長さのために全体的に内容網羅性は 低いが, 提案手法のいずれもべースラインの KWIC を上 回った . 提案手法のバリエーションの比較により，文短

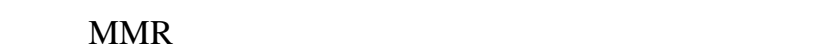
弚れらを統合した提案手法の (4) が最も高い評価である ことがわかった .

\section{5. 考察}

\section{$5 \cdot 1$ Web ページの検索結果に対する考察}

実験結果について考察する . 適合性判定の F 值が最も 高かった提案手法の (4) とベースラインの KWIC とを比 較する．まず，提案手法とベースラインにおける適合性 判定の差分を表 5 に挙げる. ベースラインでは正しく適 合性判定が出来なかったページか提案手法では正しく適 合性判定ができるようになった場合と，反対にベースラ インでは正しく判定できていたが提案手法では誤って判 定した場合について, 弚れ判定の変化の件数を示 した . 特に顕著なのは表 5 の分類 B で, 原文が不適合な 文書に対して適合から不適合に正しく判定できた事例が 他よりも多かった .このことは提案手法の適合率が向上 したことを裏付けているといえる.評価者 3 名のうち 2 名の判定結果が一致する例を分類ごとに表 6 に示す．た だし , 分類 $\mathrm{B}$ と $\mathrm{D}$ は一部のみを示している . 分類 $\mathrm{A}$ の例 は，KWICでは 2つのキーワードか離れていたために文 脈が不明であるため誤って不適合と判定された例である

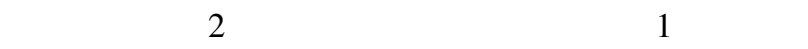
ワードを含む文における文短縮か効果的に機能し，正し く適合すると判定された . 分類 B の例では, KWIC は 3 つのキーワードをすべて含むことから誤って適合と判定 された例である . 提案手法では 1 つのキーワードしか含 まないが述部をルートとする文短縮により文脈が明らか になり，正しく不適合と判定された．実験結果では分類 $\mathrm{B}$ が最も多かったが，不適合文書に対して不適合である ことを示す概要文を生成するには，たとえキーワードを 落としても述部をルートとする文短縮が有効であること を確認した，一方，分類 Cでは，検索質問が「料理，切 り方, 名称」の例では「料理」の近傍に「講習会」がある ため正しく不適合と判定された例である．提案手法では このような不適合となりえる情報か落ちたために誤って 適合と判定された . 分類 D のひとつめの例では, KWIC では 3 つのキーワードが十分な文脈を伴って含まれてい るために正しく適合と判定された例である . 提案手法で は，KWIC の抽出対象と同じ文について文短縮を行った が, 目的の要約長の範囲で述部をルートとする部分木を 採用するという制約により，キーワードのひとつである 「訴訟」か落ちてしまい, Web ページのタイトルにもこの キーワードがなかったため誤って不適合と判定された . こ のことから，キーワードによっては落としてよいものと 落としてはいけないものがあることがわかり，Web ペー ジのタイトルの情報を含めてこれらをどのように判別す るかという課題が明らかになった .

さらに, 3 名の評価者全員の適合性判定が一致する文書 のみを対象とした場合についての評価結果を示し，提案 手法の有効性を考察する. 評価尺度は, 延べ文書数で行っ たときと同樣に，再現率と適合率とした．再現率は，原 文の評価が 3 名とも適合で一致する文書数に対する，原 
文と概要文の評価が 3 名とも適合で一致する文書数の割 合と定義した . 適合率は, 概要文の評価が 3 名とも適合 で一致する文書数に対する，原文と概要文の評価が 3 名 とも適合で一致する文書の割合と定義した．3 名の適合 性判定が一致する場合では, ベースラインが再現率 0.46 . 適合率 0.34 で，提案手法は再現率 $0.65 \cdot$ 適合率 0.52 で あった .つまり，再現率は 1.4 倍，適合率は 1.5 倍に向 上した．一方，3名全員の原文の評価が適合で一致する 文書数が 26 であったのに対し，3名の評価者光れ光れが 適合と判定した原文の文書数は 44, 53, 49 であった . こ れは，ある評価者の原文を適合と判定した 44 文書から 原文の情報とまったく過不足のない情報を含む概要文が 作られたと仮定しても，別の評価者によってこのうちの 26 の概要文は原文が 3 名とも適合と判定されているので 概要文も適合と判定されるが, 残りの 18 の概要文は原 文が 3 名とも適合と判定されていないので概要文は不適 合と判定されることを意味する . これを 3 名の評価で平 均すると，3名光れ光れの評価者が適合と判定した文書 数に対する, 3 名全員が適合の判定で一致した 26 文書の 割合の平均は， $(26 / 44+26 / 53+26 / 49) / 3=0.53$ であ り，この值が適合率の上限値に相当するといえる．以上 により，提案手法は適合性判定において有効である．

次に，適合と判定された原文において KWIC に比へてて 提案手法の内容網羅性が 2 以上向上した件数と 2 以下低 下した件数を表 7 に示す. 2 以上向上するとは，例えば 2 から 4 に上がった場合や 1 から 5 に上がった場合を指 す. 表 7 より提案手法では内容網羅性を 10 件低下させ はしたが 37 件も向上させていることから，適合性判定 の結果が同じ適合であっても提案手法はより内容のある 概要文を多く生成できたことがわかる．また，すべての 文書と評価者の組み合わせにおいて, 内容網羅性と適合 性判定の正解の相関を求めた . ただし，適合性判定の正 解として，原文と要約のいずれも適合であるとした . 計 算の結果， 0.504 の相関係数が得られた .このことから， 内容網羅性が高い概要文は, 検索質問に適合するととも に，Web ページ自身も検索質問に適合する傾向にあると 言える. 評価者 3 名のうち 2 名の評価が一致した例の一 部を表 8 に示す.これらの例からわかるように，KWIC では Web ページのタイトルと内容が重複していることが わかる . 内容が重複する分だけ概要文に盛り込める情報 が少なくなり，KWIC の内容網羅性は低かったと判断で きる.これに対して，提案手法では重要文抽出の過程に おいて MMR により Web ページのタイトルとの重複を 避けていることで, 内容網羅性を高めることができたと いえる。

\section{$5 \cdot 2$ FAQ 要約への適用に対する考察}

提案手法はキーワードを与えれば関連する文書から非 常に短い要約を作成する技術であり，乥の応用先として QA サイトを携帯端末に表示するための質問と回答の簡
ベースラインと提案手法における適合性判定の差分

\begin{tabular}{c|c|c|c|c}
\hline \hline 差分 & 原文の判定 & 要約の判定の変化 & 件数 & 分類 \\
\hline 改 & 適合 & 不適合 $\rightarrow$ 適合 & 13 & $\mathrm{~A}$ \\
\cline { 2 - 5 } 善 & 不適合 & 適合 $\rightarrow$ 不適合 & 52 & $\mathrm{~B}$ \\
\hline 改 & 不適合 & 不適合 $\rightarrow$ 適合 & 16 & $\mathrm{C}$ \\
\cline { 2 - 5 } 悪 & 適合 & 適合 $\rightarrow$ 不適合 & 19 & $\mathrm{D}$ \\
\hline
\end{tabular}

表 7 内容網羅性に大きな変化があった件数

\begin{tabular}{l|c|c}
\hline \hline 差分 & 件数 & 分類 \\
\hline 内容網羅性が 2 以上向上 & 37 & 向上 \\
内容網羅性が 2 以下低下 & 10 & 低下 \\
\hline
\end{tabular}

潔な要約の作成が考えられる. 質問の要約は最初の一文 を表示すれば十分と考え, 回答の要約に提案手法を適用 したときの有効性を調査するために，FAQデータを用い た追加実験を行った．質問と弚れに対する回答からなる FAQ データに対して，質問からキーワードを抽出し，光 のキーワードを検索質問とみなして回答の要約に適用し た. FAQデータは, 公開されている Yahoo!知恵袋デー タを用い, 2004 年 7 月の質問でカテゴリが「レシピ・調 理法」,「料理・食材」,「家事」のいずれかで，対応する 回答 (ベストアンサー) の長さが 500 バイト以上のうち， 方法や手段を問う how 型質問と思われる質問を人手で抽 出した 274 文書を対象とした . how 型を対象としたのは， 理由を問う why 型や定義を問う definition 型に比べて要 約の手がかりとなる明示的な情報が少なく，特に手がか り語などを用いない提案手法の評価に適していると考え たからである。

文書頻度と共起頻度は知恵袋データの質問と回答のす べてから獲得し，文節連接確率のモデルは毎日新聞 2003 年から 2007 年までを対象に学習した . 各質問に存在す

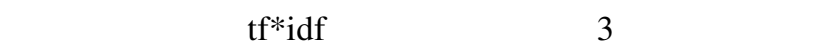
のキーワードとした . 提案手法との比較として, 先頭か ら指定したバイト数だけを抽出するリード手法と，質問 に依存せず回答に含まれる単語の $\mathrm{tf} * \mathrm{idf}$ 值による重要文 抽出と文短縮による方法を用いた。重要文抽出と文短縮 の適用に対する考え方は提案手法と同樣に, 目的の要約 長を越えるまで文を抽出し，選択済みの文が目的の要約 長の 8 割に満たず次に選択する文を含めると目的の要約 長を越える場合に，次に選択する文を残りの要約長の範 囲て短縮する . 提案手法との違いは，提案手法は質問に 含まれるキーワードと単語の相関として対数尤度比を用 いるのに対して，tf*idf 值による重要文抽出と文短縮の 方法は質問の情報を用いない点である.目的の要約長は 携帯端末への表示を前提とし, 質問の要約と同時に提示 することを想定して，さらに短い 50 バイトに設定した . 評価基準は回答の要約の読みやすさである可読性と答え としての良さである応答性を各 5 段階とし，4名の評価 
表 6 ベースラインと提案手法における適合性判定の変化の事例

\begin{tabular}{|c|c|c|}
\hline $\begin{array}{l}\text { 分類 } \\
\text { 検索質問 }\end{array}$ & $\begin{array}{l}\text { タイトル } \\
\text { KWIC }\end{array}$ & $\begin{array}{l}\text { URL } \\
\text { 提案手法 }\end{array}$ \\
\hline $\begin{array}{l}\text { A } \\
\text { 作家の値打ち, } \\
\text { 福田和也 }\end{array}$ & $\begin{array}{l}\text { スーパーダイアローグ } \\
\text { は行 - ふ. - 福田和也 } \square \text { 本 - ジャ... の回。特に「作家の值 } \\
\text { 打ち」で最低点 }\end{array}$ & $\begin{array}{l}\text { http://imc.mechamilk.com/item/4898151361/ } \\
\text {... 福田和也の... 知識量と、頭の回転の速さに感心させら } \\
\text { れる。 }\end{array}$ \\
\hline$\overline{\mathrm{A}}$ & 消痛術 & http://www.bamcreation.com/i/kafun/ \\
\hline $\begin{array}{l}\text { 花粉症, 予防 } \\
\text { 法 }\end{array}$ & $\begin{array}{l}\text { 粉 バスターズ 予防法から治療法まで...きましょう。1花 } \\
\text { 粉症の薬 } 2 \text { 治療方法 }\end{array}$ & $\begin{array}{l}\text { スギ花粉... 予防法から治療法まで完全網羅。…しておき } \\
\text { ましょう。 }\end{array}$ \\
\hline B & 料理の専門学校以外で & $\begin{array}{l}\text { http://www.casphy.com/bbs/test/r.cgi/cook/1208700437/- } \\
10\end{array}$ \\
\hline $\begin{array}{l}\text { 料理, 切り方, } \\
\text { 名称 }\end{array}$ & $\begin{array}{l}\text { 料理の専門学校以外で 料理板 Ads ... 菜の切り方 (むき } \\
\text { 方までいろいろ名称が }\end{array}$ & $\begin{array}{l}\text {... 包丁の使い方やだしの取り方、... 本などでも勉強でき } \\
\text { ると思います。 }\end{array}$ \\
\hline $\mathrm{B}$ & column & $\begin{array}{l}\text { http://www.a-park.com/column/column.php?mode=disp } \\
\& \text { yyyy=2005\&mm=05\&dd=13 }\end{array}$ \\
\hline $\begin{array}{l}\text { タバコ, 害, 訴 } \\
\text { 訟 }\end{array}$ & $\begin{array}{l}\text { をつけ、タバコメーカーを相手に訴訟を起こす...『吸い } \\
\text { すぎれば害である』と分 }\end{array}$ & $\begin{array}{l}\text {... 大量喫煙をした結果の責任が、... 困難さを引き起こし } \\
\text { たのでした。 }\end{array}$ \\
\hline$\overline{\mathrm{C}}$ & $\begin{array}{l}\text { 岡崎市/市民協働推進課/平成 } 18 \text { 年度市民協働事業公募事 } \\
\text { 業選定事業一覧 }\end{array}$ & $\begin{array}{l}\text { http://keitai.city.okazaki.aichi.jp/auto/www.city.okazaki.aichi } \\
\text {.jp /yakusho/ka2605/ka067.htm }\end{array}$ \\
\hline $\begin{array}{l}\text { 料理, 切り方, } \\
\text { 名称 }\end{array}$ & $\begin{array}{l}\text { もを対象にした料理講習会の開催 第... : 魚屋さん-魚の } \\
\text { 名称・種類、魚をさ }\end{array}$ & $\begin{array}{l}\text {... 魚屋さん-魚の名称 · 種類、魚をさわる } \ldots \text { さしみの切 } \\
\text { り方、試食) }\end{array}$ \\
\hline $\begin{array}{l}\mathrm{C} \\
\text { 世界遺産, 日 } \\
\text { 本 }\end{array}$ & $\begin{array}{l}\text { 世界遺産ブームの日本 } \\
\text { 世界遺産ブームの日本 世界遺産ブームの日本 日本の世界 } \\
\text { 遺産はいくつあるの }\end{array}$ & $\begin{array}{l}\mathrm{http} / / / \text { lipta.net/sekaiisanboom/ } \\
\text { 日本にある世界遺産とこれから登録されそうな世界遺産 } \\
\text { を紹介します。 }\end{array}$ \\
\hline $\begin{array}{l}\mathrm{D} \\
\text { タバコ, 害, 訴 } \\
\text { 訟 }\end{array}$ & $\begin{array}{l}\text { ヒロコラム } \\
\text { こ会社を訴える」訴訟が....。 タバコを吸っている人の多 } \\
\text { くは、タバコの害に }\end{array}$ & $\begin{array}{l}\text { http://www.fmyokohama.co.jp/i/column/154.html } \\
\text {... 人の多くは、タバコの害について知っているだろうし... } \\
\text { 同じでしょ? }\end{array}$ \\
\hline $\mathrm{D}$ & 未成年喫煙問題・藤沢市回答 & $\begin{array}{l}\text { http://www.cityfujisawa.ne.jp/ 559- } \\
\text { mori/simin/Fmondai/tabako/kituenM.html }\end{array}$ \\
\hline $\begin{array}{l}\text { タバコ, 害, 訴 } \\
\text { 訟 }\end{array}$ & $\begin{array}{l}\text { くでタバコを... 害金額を算出して訴訟に持ちこんでいる } \\
\text { のですが、藤沢市の損害 }\end{array}$ & $\begin{array}{l}\text {... 害から守ることを } . . . \text { するもので、... 注意することがう } \\
\text { たわれています。 }\end{array}$ \\
\hline
\end{tabular}

表 8 内容網羅性に大きな変化があつた事例

\begin{tabular}{|c|c|c|}
\hline $\begin{array}{l}\text { 分類 } \\
\text { 検索質問 }\end{array}$ & $\begin{array}{l}\text { タイトル } \\
\text { KWIC }\end{array}$ & $\begin{array}{l}\text { URL } \\
\text { 提案手法 }\end{array}$ \\
\hline 向上 & $\begin{array}{l}\text { 低カロリーで超満腹！無敵のダイエット食品 !! ガマンの } \\
\text { ダイエットはもう終わり!! }\end{array}$ & http://shopping46.6japan.net/ \\
\hline $\begin{array}{l}\text { 低 カロリー, } \\
\text { お菓子, 食品 }\end{array}$ & $\begin{array}{l}\text { 低カロリーで超満腹 ! 無敵のダイエット食品 !! ガマ...め } \\
\text { んやらお菓子やらを }\end{array}$ & $\begin{array}{l}\text {... お菓子やらを食べていたのをやめて ... 豆乳クッキーに } \\
\text { した結果。 }\end{array}$ \\
\hline 向上 & $\begin{array}{l}\text { Anti-Smoke Site BLOG <東京地裁＞事業者に煙害防止配 } \\
\text { 慮義務 タクシー禁煙訴訟で }\end{array}$ & http://www.anti-smoke-jp.com/blog/?ID=123 \\
\hline $\begin{array}{l}\text { タバコ, 害, 訴 } \\
\text { 訟 }\end{array}$ & $\begin{array}{l}\text { 裁 > 事業者に煙害防止配慮義務 タクシー禁煙訴訟で [タ } \\
\text { バコ問題関連] Comme }\end{array}$ & $\begin{array}{l}\text {... からだとして、... 損害賠償を求めた訴訟の判決で、... } \\
\text { 請求を棄却した。 }\end{array}$ \\
\hline 向上 & 運転免許の点数制度について & http://www.eonet.ne.jp/ da910/unten2.html \\
\hline $\begin{array}{l}\text { 点数制度, 運 } \\
\text { 転免許 }\end{array}$ & $\begin{array}{l}\text { 運転免許の点数制度について 運転免許の点数制度につい } \\
\text { て。主な点数表は }\end{array}$ & $\begin{array}{l}\ldots . \text { 免許停止の前科がある場合は、... 免許停止や取り消し } \\
\text { の... ことも }\end{array}$ \\
\hline 向上 & 花粉症の対策と予防 & http://kafun.moba-info.net/ \\
\hline $\begin{array}{l}\text { 花粉症, 予防 } \\
\text { 法 }\end{array}$ & $\begin{array}{l}\text { 花粉症の対策と予防 花粉症の対策と予防法 適切な花粉症 } \\
\text { 対策や予防法でつら }\end{array}$ & $\begin{array}{l}\text { 適切な花粉症対策や予防法でつらい花粉症の季節を乗り } \\
\text { 切りましょう! }\end{array}$ \\
\hline 向上 & 花粉症をやっつけろ [無料 HP MINX] & http://my.minx.jp/kahun \\
\hline $\begin{array}{l}\text { 花粉症, 予防 } \\
\text { 法 }\end{array}$ & $\begin{array}{l}\text { 花粉症をやっつけろ [無料 HP MINX] 花粉症をやっつけ } \\
\text { ろイヤ〜な花粉か飛ん }\end{array}$ & $\begin{array}{l}\ldots . \text { 鼻炎に関して } \ldots \text { Uどくなっちゃった時は } \cdots \ldots . . . \text { 花粉症予 } \\
\text { 防茶の最終兵器 }\end{array}$ \\
\hline $\begin{array}{l}\text { 向上 } \\
\text { 世界遺産, 日 } \\
\text { 本 }\end{array}$ & $\begin{array}{l}\text { 旅行情報.mobi | 日本の世界遺産 } \\
\text { | 日本の世界遺産 世界遺産を巡る 過去から受け継がれる } \\
\text { 地球の宝物 日本国 }\end{array}$ & $\begin{array}{l}\text { http://www.ryokou-j.mobi/world_heritage/ } \\
\text { 日本国内にも } 14 \text { の世界遺産があります。 ... 検索・宿泊予 } \\
\text { 約も可能です。 }\end{array}$ \\
\hline
\end{tabular}


表 9 FAQ の回答の要約に対する可読性と応答性の評価

\begin{tabular}{l|c|c}
\hline \hline & 可読性 & 応答性 \\
\hline リード手法 (ベースライン) & 2.15 & 2.69 \\
tf*idf 值による文抽出・文短縮 & 3.29 & 2.65 \\
提案手法 & 3.51 & 2.70 \\
\hline
\end{tabular}

者により評価した 。

表 9 に可読性と応答性に対する 4 名のスコアの平均値 を示す． 提案手法は, ベースラインであるリード手法と 同等の応答性を保ちながら可読性を向上させたことがわ かる．また，tf*idf 值による重要文抽出・文短縮ではべー スラインよりも可読性が上がるものの応答性か下がるこ とがわかった . これは質問に対する回答は比較的文章の 先頭に現れるために応答性は下がらないが, 途中で文が 切れてしまうことによる可誌性の問題が大きいと考えら れる．一方，tf*idf 值による重要文抽出・文短縮では，述 部をルートとする文抽出により文の途中で切れることは なくなるので可読性は上がるが，質問から抽出したキー ワードとの対数尤度比を用いる提案手法ほどには応答性 が上がらず，tf*idf 值では不十分であることがわかった . 提案手法は，質問から抽出したキーワードが回答に存在 しない場合もある中で，キーワードと相関の高い文を抽 出することでベースラインと同等の応答性を維持した . また，述部をルートとする文短縮により文の途中で切れ る問題を解消し可読性を向上させた .これらより，携帯 端末への表示を想定した 50 バイトという非常に短い要 約長の制限のもとで，提案手法は可読性と応答性を両立 させたといえる .

\section{6. ま と め}

本論文では，携帯端末へ表示するのに適した，検索質問 に依存したテキスト要約の新たな手法を提案した .キー となるアイデアは, すでに選択した文との重複を排除し ながら検索質問との相関に基づき検索質問に適合する文 を選択する重要文抽出と，述部をルートとした部分木の 中から文節網羅率と文節連接確率に基づくスコアが最も 大きい部分木を出力する文短縮である . 評価実験の結果 ， 検索の適合性判定と, 要約の文法性と非冗長性と内容網羅 性のすべてにおいて，KWICによるべースラインを上回 ることを確認した，適合性判定では，特に不適合な Web ページから正しく不適合と判定できる概要文を多く生成 したことにより適合率が上昇した．また，内容網羅性が 高い概要文は検索質問に適合し Web ページもまた検索 質問に適合する傾向があり，適合という同じ判定結果に おいても内容網羅性が大きく向上した概要文か増加した . 不適合な Web ページにおける概要文の生成として，提案 手法は KWICによるべースラインよりも有効であること か確認できたが，どのような情報を提示してどのような 情報を提示しないのがさらに良いのかという課題につい
ては , 今後も検討を続けていきたい .

謝辞

本研究の実施にあたっては, 国立情報学研究所が提供 している NTCIR-4 Web テストコレクションの Web 検索 評価データと, ヤフー株式会社が国立情報学研究所に提 供した Yahoo!知恵袋データを利用させていただきました .

\section{$\diamond$ 参 考 文 献 $\diamond$}

[Banko 00] Banko, M., Mittal, V., and Witbrock, M.: Headline Generation Based on Statistical Translation, in Proc. of the 38th Annual Meeting of the Association for Computational Linguistics (ACL2000), pp. 318-325 (2000)

[Berger 00] Berger, A. and Mittal, V.: Query-Relevant Summarization using FAQs, in Proc. of the 38th Annual Meeting of the Association for Computational Linguistics (ACL-2000), pp. 294-301 (2000)

[Carbonell 98] Carbonell, J. and Goldstein, J.: The Use of MMR, Diversity-Based Reranking for Reordering Documents and Producing Summaries, in Proc. of the 21th Annual International ACM/SIGIR Conference on Research and Development in Information Retrieval, pp. 335-336(1998)

[Dang 06] Dang, H. T.: DUC 2005: Evaluation of Question-Focused Summarization Systems, in Proc. of the Workshop on Task-Focused Summarization and Question Answering, pp. 48-55 (2006)

[Dunning 93] Dunning, T.: Accurate Methods for the Statistics of Surprise and Coincidence, Computational Linguistics, Vol. 19, No. 1, pp. 61-74 (1993)

[平尾 08] 平尾 努, 鈴木 潤, 磯崎 秀樹: 軽量な文短縮手法, 言語処理 学会第 14 回年次大会講演論文集 (NLP2008), pp. 484-487 (2008) [堀 01] 堀 智織, 古井 貞熙 : 講演音声の自動要約の試み, 話し言葉 の科学と工学ワークショップ, pp. 165-171 (2001)

[今村 07] 今村賢治:系列ラベリングによる準話し言葉の日本語係 り受け解析, 言語処理学会第 13 回年次大会講演論文集 (NLP2007), pp. 518-521 (2007)

[森 02] 森 辰則 : 情報検索表示向け文書要約における情報利得比 に基づく語の重要度計算, 自然言語処理, Vol. 9, No. 4, pp. 3-32 (2002)

[Nomoto 08] Nomoto, T.: A Generic Sentence Trimmer with CRFs, in Proc. of the 46th Annual Meeting of the Association for Computational Linguistics (ACL-2008), pp. 299-307 (2008)

[大森 03] 大森 岳史, 増田 英孝, 中川 裕志: Web 新聞記事の要 約と炎の携帯端末向け記事による評価, 情報処理学会研究報告 NL153-1, pp. 1-8 (2003)

[酒井 02] 酒井 浩之, 篠原 直嗣, 増山 繁, 山本 和英 : 連用修飾表現 の省略可能性に関する知識の獲得, 自然言語処理, Vol. 9, No. 3, pp. 41-62 (2002)

[高見 08] 高見 真也, 田中 克己 : ウェブ検索結果における検索目 的に応じたスニペット生成, 情報処理学会論文誌, Vol. 49, No. 4, pp. 1648-1656(2008)

[Tombros 98] Tombros, A. and Sanderson, M.: Advantages of Query Biased Summaries in Information Retrieval, in Proc. of the 21st Annual International ACM/SIGIR Conference on Research and Development in Information Retrieval, pp. 2-10 (1998)

[Yamagata 06] Yamagata, K., Fukutomi, S., Takagi, K., and Ozeki, K.: Sentence Compression Using Statistical Information About Dependency Path Length, in Proc. of the 9th International Conference on Text, Speech and Dialogue, TSD 2006, (Lecture Notes in Computer Science / Lecture Notes in Artificial Intelligence, Vol.4188), pp. 127-134 (2006)

[山本 05] 山本 和英, 池田 諭史, 大橋 一輝 :「新幹線要約」のため の文末の整形, 自然言語処理, Vol. 12, No. 6, pp. 85-111 (2005)

\section{〔担当委員：難波 英嗣〕}

2009 年 4 月 28 日 受理 


\section{著 者 紹 介}

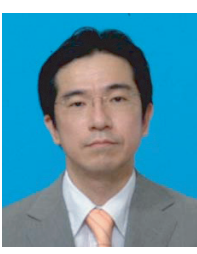

長谷川 隆明(正会員)

1992 年慶應義塾大学理工学部電気工学科卒業. 1994 年同 大学院理工学研究科計算機科学専攻修士課程修了. 同年, 日本電信電話株式会社入社. 2003 年 2004 年ニューヨー ク大学客員研究員. 現在, NTT サイバースペース研究所 主任研究員, 東京工業大学大学院総合理工学研究科知能 ステム科学専攻博士課程在学中. 自然言語処理, 情報アク セス技術の研究開発に従事. 情報処理学会, 言語処理学会 各会員.

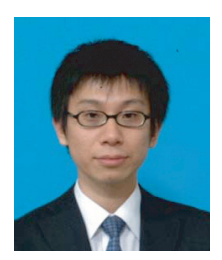

\section{西川仁}

2008 年慶應義塾大学大学院政策・メディア研究科修士課 程修了. 同年日本電信電話株式会社入社. 現在, NTT サ イバースペース研究所にて自然言語処理技術の研究開発に 従事. 言語処理学会会員.

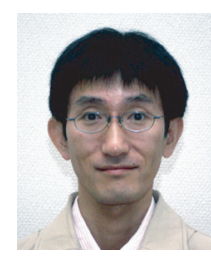

\section{今村 賢治}

1985 年千葉大学工学部電気工学科卒業. 同年日本電信電 話株式会社入社. 2000 年 2006 年 ATR 音声言語コミュ ニケーション研究所. 2006 年より NTT サイバースペース 研究所主任研究員. 現在に至る.主として自然言語処理の 研究・開発に従事。博士 (工学)。電子情報通信学会, 情 報処理学会, 言語処理学会各会員.

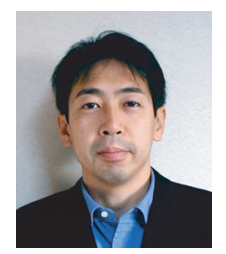

菊井 玄一郎(正会員)

1984 年京都大学工学部電気工学科卒. 1986 年 同大学院 修士課程修了. 同年日本電信電話 (株) 入社. A T R への 2 回の出向を経て, 現在, 日本電信電話 (株) サイバースペー ス研究所、音声言語メディア処理プロジェクト, 音声・言 語基盤技術グループリーダ.テキストおよび音声に対する 言語処理の研究・開発に従事. 博士 (情報学). 情報処理 学会, 電子情報通信学会, 言語処理学会各会員.

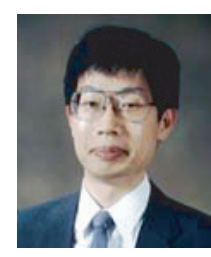

\section{奥村 学(正会員)}

1984 年東京工業大学工学部情報工学科卒業 . 1989 年同大 学院博士課程修了. 同年, 東京工業大学工学部情報工学科 助手. 1992 年北陸先端科学技術大学院大学情報科学研究科 助教授, 2000 年東京工業大学精密工学研究所助教授, 2009 年同教授, 現在に至る.工学博士. 自然言語処理, 知的情 報提示技術, 語学学習支援, テキスト評価分析, テキス卜 マイニングに関する研究に従事. 情報処理学会, AAAI, 言 語処理学会, ACL, 認知科学会, 計量国語学会各会員. 